\title{
Assessing the Role of Access to Finance for Young Potential Entrepreneurs: The Case of Romania
}

\section{Valentina Diana Rusu ${ }^{1}$ and Angela Roman²}

${ }^{1}$ Institute of Interdisciplinary Research, Social Sciences and Humanities Research Department, Alexandru Ioan Cuza University of lasi, Romania

${ }^{2}$ Faculty of Economics and Business Administration, Alexandru Ioan Cuza University of Iasi, Romania

\section{Abstract}

The significant role played by youth entrepreneurship for the economic growth of countries has shift the attention of researchers to the potential entrepreneurs, and how to stimulate the enter on the market of new and innovative individuals which might have positive effects on economic development. The present research is conducted to identify the influence of some characteristics of business environment and of access

Corresponding Author: Valentina Diana Rusu valentinadiana.ig@gmail.com

Received: 17 November 2019 Accepted: 6 January 2019 Published: 12 January 2020

Publishing services provided by Knowledge E

(c) Valentina Diana Rusu and Angela Roman. This article is distributed under the terms of the Creative Commons

Attribution License, which permits unrestricted use and redistribution provided that the original author and source are credited.

Selection and Peer-review unde the responsibility of the EBEEC Conference Committee. to financial resources on entrepreneurial intentions of faculty students from one of the largest universities of Romania. We conducted the study on a sample of undergraduate and master students, by applying a questionnaire. The main objectives of this paper are to analyze how the young potential entrepreneurs perceive the access to finance for start-ups and if this factor would be a significant predictor of the decision to become entrepreneurs of the students. In addition, our study discusses how policy makers could provide support for young people to create innovative businesses, from a financial perspective. Our findings show a high level of entrepreneurial intentions among the interviewed students, but also that easy access to financial resources is the most important obstacle identified by the students with entrepreneurial intentions. Young entrepreneurs encounter significant obstacles in trying to obtain the necessary financial resources, because they do not have a market history or sufficient guarantees. Access to information and fewer business regulations were also identified as factors with a significant contribution on entrepreneurial orientation of youth. The implications of the study are significant for potential policy intervention, because emphasize the need of the policy makers to stimulate young entrepreneurs by promoting policies that allow young entrepreneurs greater access to finance.

Keywords: young entrepreneurs, potential entrepreneurs, entrepreneurial intentions, access to finance, business environment, university students

JEL Classification Codes: L26, M13

\section{Introduction}

Entrepreneurship is acknowledged as one of the key drivers of growth because it helps create new businesses, create new jobs, increase income, reducing poverty, developing innovation and competitiveness. Also, promoting entrepreneurship among 
young people is considered an important development strategy in order to integrate them into the labour market and to capitalize on their potential to contribute significantly to economic development [1].

In recent years, entrepreneurship among students has attracted the attention of several researchers, and some studies provide empirical evidence that new businesses created by students and graduates play a significant role in bringing new knowledge to the market and in employment creation [2].

Given the rise in youth unemployment, entrepreneurship is a means not only for young people to create a job for themselves but also to create jobs for other people, especially young people, through their businesses [3--4]. However, youth entrepreneurship is seen not only as a cure for unemployment but also as an alternative to traditional forms of employment [5]. It is also argued that youth entrepreneurship can also have a social purpose, creating hope for the future and counteracting the development of social unrest, and by creating income opportunities, this type of entrepreneurship could help reduce the phenomenon of migration, which is manifested in conditions of low incomes and uncertain economic prospects in home countries [6]. Although young entrepreneurship has many benefits, young people who want to enter into entrepreneurship face a lot more obstacles in comparison with older age groups, due to limited resources and experience, including a lack of capital and insufficient funding of starting new business [5].

At EU level, since 2008, it has moved from policy to promote small and medium-sized enterprises to policy promoting entrepreneurship [5]. We therefore assist to a shift in priorities, driven by both the increase in youth unemployment in many Member States and the adoption of the Europe 2020 strategy, which has as its key objectives combating unemployment and promoting job creation. In this context, the concern of the European Commission for the promotion of entrepreneurship was marked by the adoption of the Entrepreneurship 2020 Action Plan [7], which has the main purpose to facilitate the creation of new businesses, but also to create a more favourable environment to entrepreneurs. In order to create an environment that stimulate the development of entrepreneurs the main key area targeted in this action plan is access to finance. Access to finance represents one of the most significant constraints on growth and entrepreneurship in European Union countries. Without access to the most appropriate financial resources the creation and proper development of business is hampered. The situation is even worst when we talk about start-ups. Lack of finance is a common barrier for most new enterprises and it is a key constraint for young people who want to start or develop a business [8]. 
Starting from those stated above, in this paper we aim at testing the perception of young potential entrepreneurs about the access to finance and if this perception significantly influences their future decision to become entrepreneurs. Young entrepreneurs are abler to adapt to the changing market, by bringing new economic opportunities and trends. Young people generally have IT knowledge, they can more easily integrate this knowledge into their business, thus finding new ways to promote and new markets (for example, by using the Internet and social media). Also, young people have innovative ideas, so they can generate innovative entrepreneurship. But, their early age is a deterrent for potential creditors, who due to lack of experience are more reluctant to provide financial resources to these categories of people.

In our previous research, we found that small and medium sized enterprises face more obstacles when trying to obtain financing resources comparing to large enterprises, and we expect to obtain also significant differences between young and older entrepreneurs, as regards their access to financial resources. Thus, the main objectives of this present investigation are: (i) identifying the entrepreneurial intentions of university students from Romania; (ii) identifying their perception about the business environment in Romania and the access to different financing resources; (iii) emphasizing which would be the main measures that could stimulate young people to decide in entering in entrepreneurship.

The data for our study was obtained by applying a questionnaire to university students from Alexandru loan Cuza University of lasi. Using graphical methods, we realize a visual analyzis of the results which become more clear and easy to compare with the findings of other research.

The added value of our study comes from the fact that, according to our knowledge, there are no other studies, in special focused on Romania, analyzing the problem of access to finance for young potential entrepreneurs. Thus, our research complements the gap in the literature by offering evidence regarding the significant role played by the access to finance in the decision of young potential entrepreneurs to start a business. The results obtained could be of interest to policy makers in order to help them decide which measures should apply in order to sustain more young people to become entrepreneurs. But also, could be of interest for the Universities to identify the lacks in the preparation of students, from economic studies, to become entrepreneurs.

Our paper is structured as follows: the second section presents a review of literature on youth entrepreneurship, with accent on the factors influencing the decision of young people to become entrepreneurs; the following section summarizes the methodology, describing the sample, the instrument used and the methods; in the fourth section we present and discuss the results of our research. The paper ends with conclusions. 


\section{Literature Review}

Youth entrepreneurship is a subject of interest to many researchers, who are particularly concerned with investigating factors that encourage and / or hinder young people from entering into entrepreneurship. On the other hand, youth entrepreneurship is an important concern for many governments, especially from countries that are experiencing steady growth in youth unemployment.

The interest in stimulating youth entrepreneurship is determined by the many advantages of this type of entrepreneurship, among which [9] (p. 13): youth entrepreneurship is a solution for job creation for youth; young entrepreneurs are more likely to hire other young people; young entrepreneurs are more sensitive to new opportunities and economic trends; young people are active in sectors with strong economic growth; young people who have entrepreneurial skills are better employees; young people are more innovative and often create new forms of independent work; entrepreneurship provides young unemployed with an opportunity to earn income and integrate into society.

Several studies focused on examining the factors that influence the dynamics of youth entrepreneurship in different countries (both developed and developing countries), especially the entrepreneurial intentions of university students. According to the literature [10], the main factors that determine individuals to engage in entrepreneurial activity are the individual entrepreneurship-related attributes, social capital and perception of societal attitudes, and individual demographic characteristics. Some studies [11--12] point out that among the factors that most directly influence the decision to become an entrepreneur and self-employment a key role is played by individual factors, which can be grouped into seven categories, and namely: basic individual characteristics (gender, age, and marital status and children); background (parents and spouse); personality characteristics (risk attitude and other psychological traits); human capital (education and experience); health condition; nationality and ethnicity; and access to financial resources. In terms of financial resources, Simoes et al. [11] emphasizes the existence of a positive relationship between household wealth and the decision to be self-employed.

The main financial factors that have impact on the decision to become self-employed were identified in the literature by some studies [13-14]. These studies show that the access to financing resources is very important for the individuals that decide to enter into entrepreneurship. For example, Dunn and Holtz-Eakin [13] analyze the impact of parental wealth and human capital on the likelihood of a person switching from employee to self-employment. The results of the analyzis show that young men's own 
financial assets have a modest quantitative effect on the transition to self-employment, while the capital of parents exercises great influence. Ho and Wong [14] investigate the impact of various sources of financing (such as traditional debt, venture capital and informal investments) on entrepreneurial activity in 37 countries. The survey results show that only informal investments have a positive and significant impact on the entrepreneurial propensity of the countries included in the sample.

Several other studies [15-19] have tried to identify the determinants of entrepreneurial intentions, and pointed out the main role of personality traits and personal attitude for the decision of individuals to enter into entrepreneurship. Besides this, the mentioned studies have also tested the impact of the external environment factor on the decision to start a new business, and found that, it also exert a significant influence on potential entrepreneurs. But, we have to mention that the findings are different depending on the country for which the analyzis is performed. Using a questionnaire survey on undergraduate business students in a Malaysian public university, Zain et al. [15] investigate whether business students have an intention to enter into entrepreneurship. The study also examines whether personality traits and environmental factors influence students to become entrepreneurs. The results indicate that more than half of respondents have the intention to become entrepreneurs and their decisions are attributed to the influence of their family members, academics and attending courses on entrepreneurship. The results also show that personality traits have an important influence on students' decision to become entrepreneurs while environmental factors do not influence students to become entrepreneurs. Liñan et al. [16] find that personal attitude and perceived behavioural control would be the most important factors that would influence the entrepreneurial intention of university students. Using the questionnaire survey method, Mouselli and Khalifa [17] examine the impact of demographic factors (gender, age, year of study, university, faculty, work experience), personal (need for achievement, locus of control, self-efficacy), and external (information and communication, institutional environment, crisis effect) on the entrepreneurial intentions of university students in Syria. In addition, the authors use ordinary least squares to identify the determinants of entrepreneurial intentions for students included in the sample. Research results show self-efficacy, information and communication, and institutional environment have positive and significant effects on the entrepreneurial intentions of students. A recent study [18] analyzes, based on a sample of students from four universities in Brazil and Portugal, how personal traits, self-efficacy, training and entrepreneurial education, social recognition and entrepreneurial attitude influence students 'entrepreneurial intention. Research results show that personality traits, self-efficacy, and entrepreneurial attitude 
are strong predictors of entrepreneurial intent, and the influence of social recognition and country of origin is not significant.

Turker et al. [19] examine the impact of some contextual factors on the entrepreneurial intention of university students for a sample of $\mathbf{3 0 0}$ university students in Turkey. The authors find that only educational and structural support factors would be significant predictors of entrepreneurial intention. With regard to the first factor, the study points out that, given that the university provides adequate knowledge and inspiration for entrepreneurship, the possibility of choosing an entrepreneurial career might increase among young people. In terms of structural support, the authors argue that fostering entrepreneurship requires a more comprehensive support, including the collaboration of all sectors in the society.

Some researchers (e.g., $[4,20])$ focused their attention on investigating the factors that lead young people to be entrepreneurs and self-employed. Thus, in a study, Holienka et al. [4] analyze the factors that lead young people and young adults to get involved in business start-ups in Visegrad Countries, according to their opportunity or necessity. The authors find that self-confidence and access to networks are important factors that lead both young and young adults to engage in business start-ups, regardless of their motivation. Also, research results indicate that the fear of failure and being a woman reduces the chance of business start-up in the majority of cases analyzed, and among young people, being a student significantly impedes them from engaging in entrepreneurship. Based on a survey among young adults in eleven European countries, Dvouletý et al. [20] examine the factors that lead young adults with experience of longterm unemployment to become self-employed when compared to young adults without such experiences. The authors find that the reasons why a person engages in selfemployment differs significantly between the two groups of people under consideration. The study shows that several factors, such as risk acceptance or parental role models, are less important for becoming self-employed after experiencing unemployment. In addition, the authors find that people with the experience of unemployment are focused on entrepreneurship and self-employment, especially for reasons of necessity.

Analyzing the literature in the field of youth entrepreneurship, we find that other theoretical and empirical studies have focused on discussing the reasons that lead young people to entre entrepreneurship, as well as the constraints that arise when starting a business. This studies [21-24] point out the role of access to finance for potential entrepreneurs, and describe the main measures that could motivated students to become entrepreneurs. They applied questionnaire on undergraduate students and showed that the perception of young people regarding access to finance is different 
according to the country they are located. For example, Kristiansen and Indarti [21] emphasize that access to finance is one of the most important obstacles to the start-up of new businesses, especially in developing economies with weak credit and venture capital institutions. Veciana et al. [22] highlight, based on the perceptions of the investigated students, that the main factors that support the start of new businesses are governmental support and access to financing. In addition, the authors find that the main barriers to new business creation are competition, lack of start-up capital, excessive regulation and market saturation. Keat and Ahmad [23] examine the undergraduate students' perceptions on entrepreneurship, motivations to be entrepreneurs, and obstacles that appear when deciding to start a business. The results of the study show that respondents have a favourable perception towards entrepreneurship, and extrinsic rewards and change management motivate them to start a business. With regard to obstacles, the authors find mainly financial and operational problems. Another study [9] indicates that the main obstacles faced by young entrepreneurs are limited access to finance and capital, underdeveloped or insufficient skills and lack of mentoring support. Based on the opinion of the Lithuanian undergraduate students involved in the research, Kvedaraite [24] finds that personal income would be the most important factor motivating students to become entrepreneurs. On the other hand, the author finds that the lack of information on starting a business, the reduced possibilities of getting a loan, the high cost of the loan, and the lack of entrepreneurial skills are the most important barriers to starting a business by academic youth.

\section{Methodology}

The sample of our study is consisted of university students from one of the oldest universities in Romania, Alexandru loan Cuza university of lasi. We have chosen students from the Faculty of Economics and Business Administration from undergraduate studies and also from master. We excluded the students from the first year of study from the sample because they may not have enough economic and business knowledge. The purpose of choosing this sample is because they have theoretical knowledge on how to set up and manage business and they can be considered as potential entrepreneurs. Self-report data was collected in February 2019. We applied 150 questionnaires but some of the answers were invalided because of no or multiple answers, therefore, finally we remain with a total sample of 100 students. By gender, our sample is comprised of 23 males (23\%) and 77 females (77\%). Such a result was to be expected because female students hold the overwhelming share among students from the faculty involved 
in the study. The distinction on provenience shows that 11 percent from the students interviewed are from lasi, 52 percent from other towns and 37 percent from rural zone. The distinction by area of origin is important because the preparation of future students differs greatly in rural areas, and even in small cities compared to the city of lasi. For example, in high schools, in the city of lasi, students have the opportunity to form entrepreneurial knowledge, by establishing exercise companies and participating in fairs with such companies. However, in rural areas or small cities, students do not have these possibilities, due to the lack of teachers with entrepreneurial training. Training young people in high school on entrepreneurship can play an important role in their future decision to become an entrepreneur.

For developing our study, all participants were asked to respond to a questionnaire entitled "Access to finance and entrepreneurial intentions". The questionnaire was applied in the second semester of the academic year 2018-2019 in the classroom, at the end of a lecture period and consists of 21 items, and takes around 10 minutes to be completed. Students are required to respond to items of different types, there are several demographic questions, several scale items, several items for which the respondents have to choose an option from a set of categories, and an open answer item. For most of the items, respondents had to choose the number that best describes their opinion, according to the Likert scale of 4 points (1-strong agree, 2-agree, 3disagree, 4 strongly disagree). The items from this questionnaire target several aspects including: personal characteristics of entrepreneurs, entrepreneurial education, risks and barriers in starting up a new business, sources of financing and their accessibility, needed government measures for supporting potential entrepreneurs. The questions regarding personal characteristics of potential entrepreneurs were adapted after the questionnaire entitled "Am I the Entrepreneurial Type", which can be found online on the Business Development Bank of Canada [25] website and after other papers [26--29]. The questions regarding the perception of the business environment and the access to finance for potential entrepreneurs were adapted after Business Startup Barometer in Romania [30] and Flash Eurobarometer, No. 283 [31]. The questions from the Barometer are addressed to entrepreneurs at the beginning of their activity but for our instrument we adapted them in order to fit for the potential entrepreneurs.

Before applying the questionnaire to the whole sample, we made a pilot testing on a sample of ten students, and after we have reformulated some of the initial set of items so that questions can be easily understood by the students and to get the clearest results. 
In the literature, there is a consensus that access to financial resources is an important determinant of entrepreneurship [32--36]. The problem of access to finance is more pressing for young people that want to start or grow a business. Lenders consider young people as risky investments because they do not have a credit or work history, and do not have sufficient assets to guarantee the required loans [37].

Starting from those stated above in our analyzis we intend to reveal the entrepreneurial intentions of the university students from one of the biggest universities from Romania, and also to identify if the access to finance is a significant factor that would influence their decision to start their own business.

As guiding points of our analyzis we have formulated two hypotheses, which are presented below:

Hypothesis 1: Easy access to finance positively influence the potential entrepreneurs

Hypothesis 2: The conditions from the business environment significantly influence the potential entrepreneurs

\section{Results and Discussions}

Figure 1 presents the entrepreneurial intentions of the students considered in our sample. We observe, a high level of entrepreneurial intent among students interviewed, respectively 60 percent of the students interviewed expressed their intentions to become entrepreneurs in the future. This high percentage may express an increase in young people's interest in an entrepreneurial or independent career, but may also reflect an increased perception among young people that entrepreneurship is a way forward for financial independence, given the high youth unemployment rate.

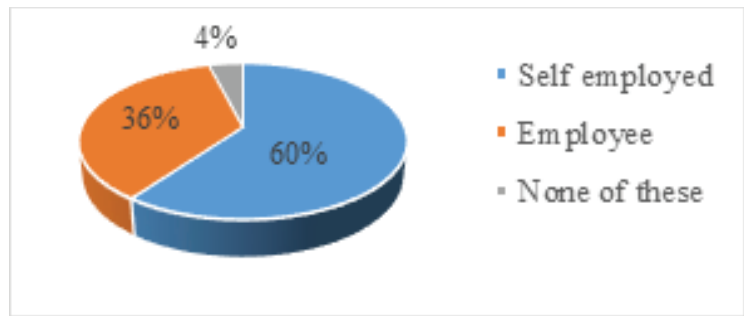

Figure 1: Entrepreneurial intentions of young potential entrepreneurs (as \% of the number of respondents). Source: authors own calculations.

According to Eurostat data, in December 2018, in Romania, the unemployment rate among young people was among the highest in the EU countries, respectively 15.4 percent, due to the difficulties that young people face in finding a job. 


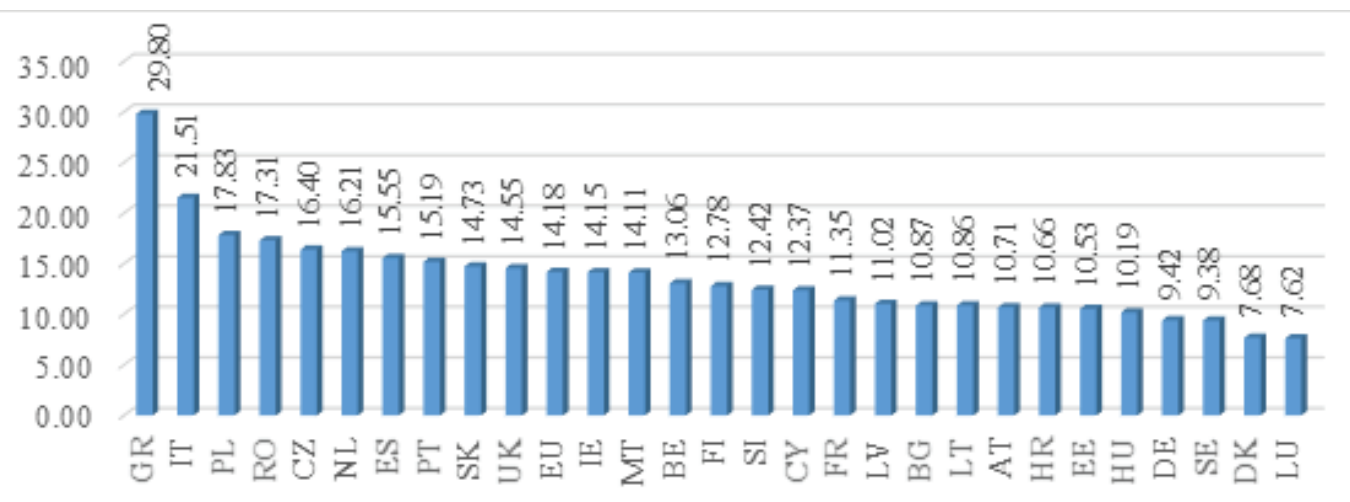

Figure 2: Self-employed persons aged 15 to 74 in the eu-28, 2018 (of total employment). Source: authors own calculations based on Eurostat data [38].

Also, the results of our survey are in line with the economic reality, which indicates, according to Eurostat data [38], that Romania is among the EU countries with the highest self-employed rate (see Figure 2), respectively almost one in every three people in employment were self-employed in 2018 (17\%).

Regarding young people, we note that among the EU countries, Romania has the highest self-employed rate with the age between 15 and 24 , respectively 12 percent in 2018, exceeding almost four times the EU average (see Figure 3).

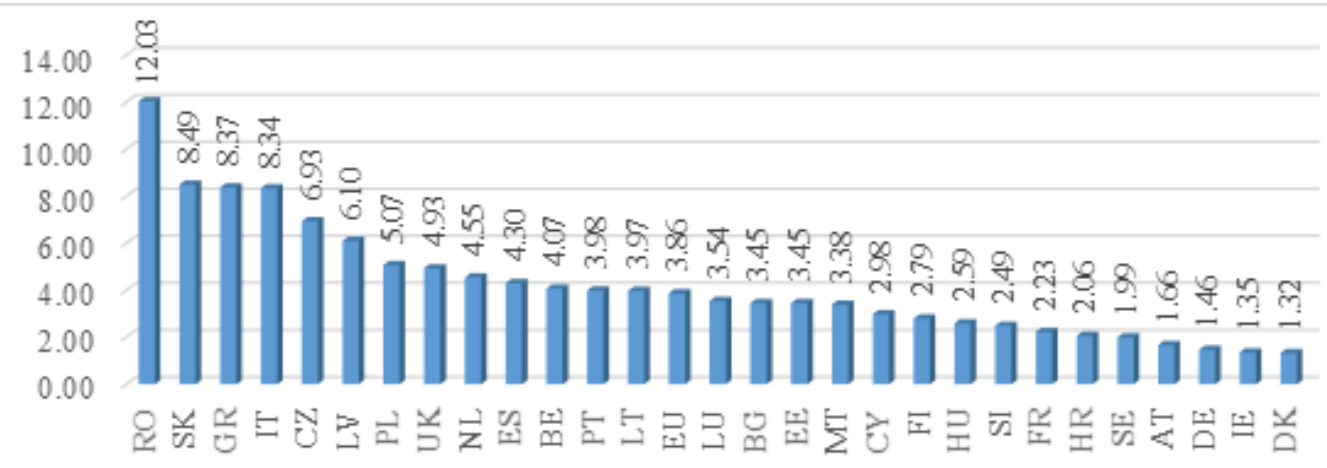

Figure 3: Self-employed persons aged 15 to 24 in the eu-28, 2018 (of total employment). Source: authors own calculations based on Eurostat data [38].

Based on our survey of entrepreneurial intentions of the students, we find that 36 percent of the respondents indicated that they want to find a job after graduation, and only 4 percent chose none of these options. To explain the last percentage, we have to keep in mind the phenomenon of parents' migration for jobs that become dominating in Romania in the last years. Thus, this 4 percent of students might want to follow the footsteps of a parent or a relative and leave to work abroad after graduation.

In the same time, asked about what would they do with the money if they suddenly inherited 300.000 lei, more then half (57\%) of the respondents say that they will start a 


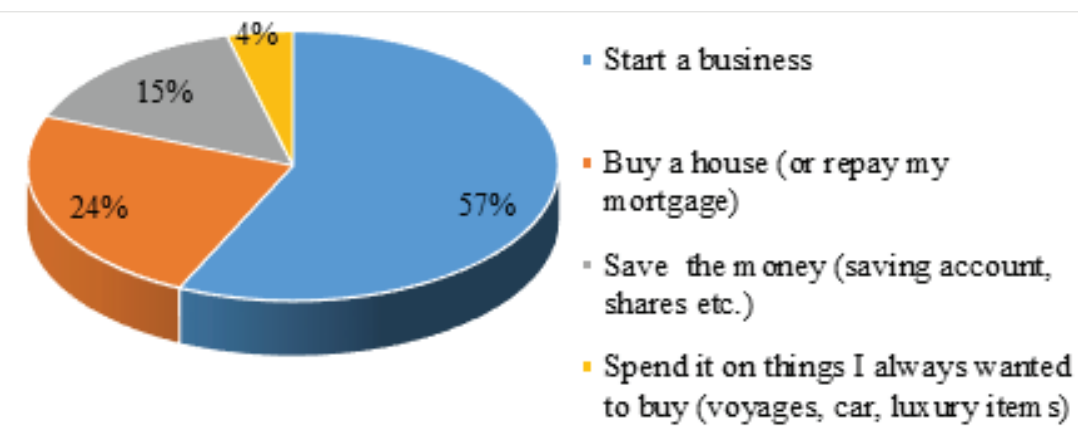

Figure 4: What would you do with the money if you suddenly inherited 300.000 lei?. Source: authors own calculations.

business, alone or with a partner. A quarter of the students say that they will buy a house, and 15 percent would save the money. Only 4 percent of the individuals would spend the money on something that they have always wanted to buy, such as a holiday or a car (see Figure 4). The purpose of this question was, to see, if the obstacles coming from lack of financial resources were removed, how many young individuals would decide to become entrepreneurs. The results obtained confirm Hypothesis 1 that easy access to financial resources stimulates potential entrepreneurs.

It is encouraging to see that although students have had the option of answering that they would work less or stop working, not even one of them has chosen this option. This highlights the young people's desire to work, to exploit their potential. The result obtained above, presented in Figure 1 and 4, point out that the entrepreneurial intentions of young potential entrepreneurs from Romania are high, and this should attract the attention of policy makers that are interested in sustaining the economic development of country by a qualitative entrepreneurship. Young individuals have high innovative potential, have knowledge of using new information technologies and could apply them in the business they create. In order to complete our results, and to offer a better image of the factors that are discouraging or stimulating the young individuals to become self-employed we continued our investigations with several other questions that are described in the following.

Young people opt for starting a business for a wide range of reasons. Thus, in the case of our analyzis, asked about the reasons why they would prefer to become entrepreneurs, we find that the motivation ranges from personal independence/selffulfilment/interesting tasks, freedom to choose place and time of working, better income prospects to favourable economic climate (see Figure 5). So, more than half of the respondents (53\%) chose personal independence, self-fulfilment or interesting tasks. One quarter of the students interviewed said that the reason for which they what to become entrepreneurs is the freedom to choose the place and time of working. 
Our results are in line with those obtained by Flash Eurobarometer, no. 283 [31], which showed that 68 percent of the EU citizens expressed their preference for selfemployment because of personal independence, self-fulfilment and the chance to do something of personal interest, and 35 percent mentioned as a reason of involving in entrepreneurship the freedom to choose their own place and time of work. The third reason is better income prospects, answer chosen by 12 percent of the respondents. Neither one of the respondents said that they would want to become entrepreneurs to contribute to the society.

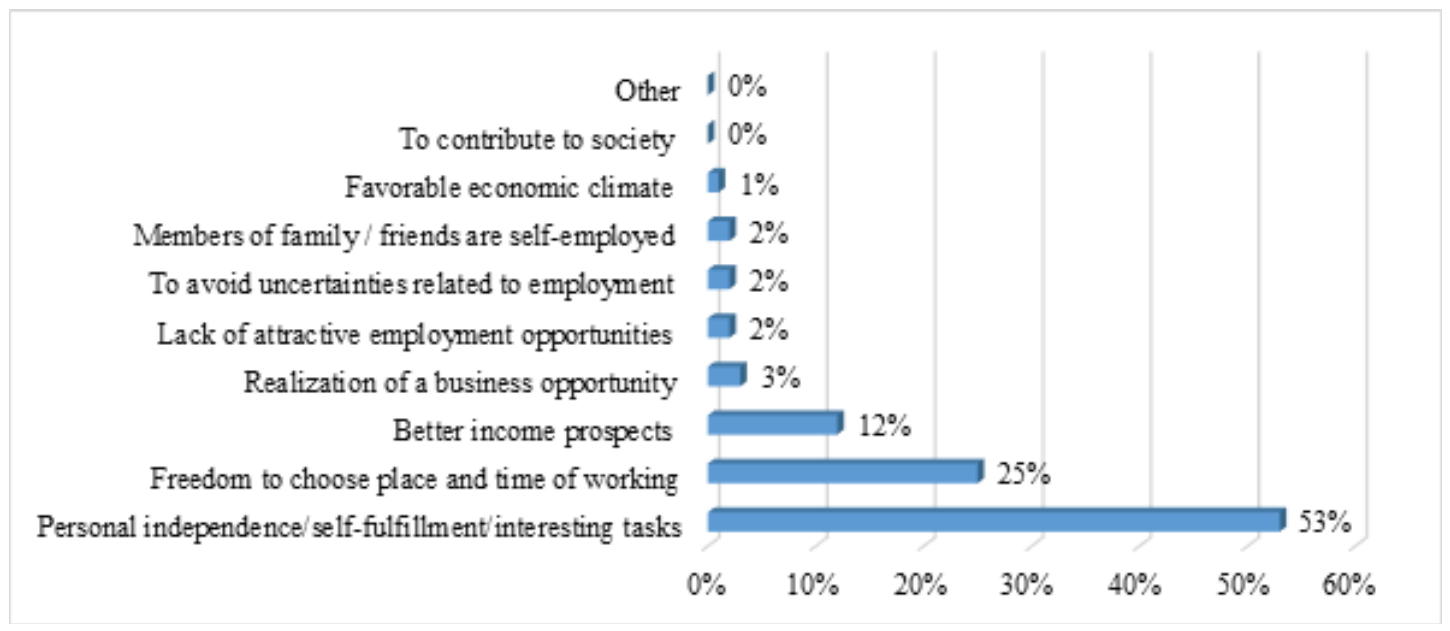

Figure 5: Reasons for choosing to become entrepreneur. Source: authors own calculations.

Only 2 percent of the respondents said that the reason for which they would become entrepreneurs is the fact that member of family or friends are self-employed. Although when asked if they have family members or friends that are entrepreneurs the responses where almost equilibrated (44\% answered yes and $56 \%$ no). Hence, we conclude that the personal model offered by close friends or relatives who are entrepreneurs is not a factor influencing positively the decision to become self-employed, perhaps because having close contact with them the young people know the difficulties faced when starting up a new business or the difficulties faced by the already established entrepreneurs in Romania and this fact is discouraging them. The study of Tiftik and Zincirkiran [28] shown that the biggest factor directing young individuals towards entrepreneurship was their parents, other family members, friends and their teachers. Thus, their study emphasize that social support can motivate the young individual to tolerate the uncertainty and take risk. The authors pointed out the important role of the structure of the society in which the individual lives. If the structure and culture of the society support entrepreneurship, the more people are likely to become an entrepreneur in that society. Related to this, our findings come in addition to those from Business Startup Barometer in Romania [30] where 60 percent of respondents said that entrepreneurship is not supported by 
Romanian mentality and values. Knowing the reasons why young people choose to be entrepreneurs can be important for policy makers interested in identifying appropriate measures that will lead to an increase in the start-up of new businesses in order to develop the economy.

As for reason why young potential entrepreneurs would prefer to be an employee rather than self-employed 4 in 10 respondents chose regular and fixed income (see Figure 6), similar with the findings of Flash Eurobarometer, No. 283 [31] for the case of the EU citizens. The second reason is stability of employment and fixed working hours mentioned by 16 percent of the respondents. The lack of financial resources is the third reason chose by 8 percent of the students who responded to the questionnaire.

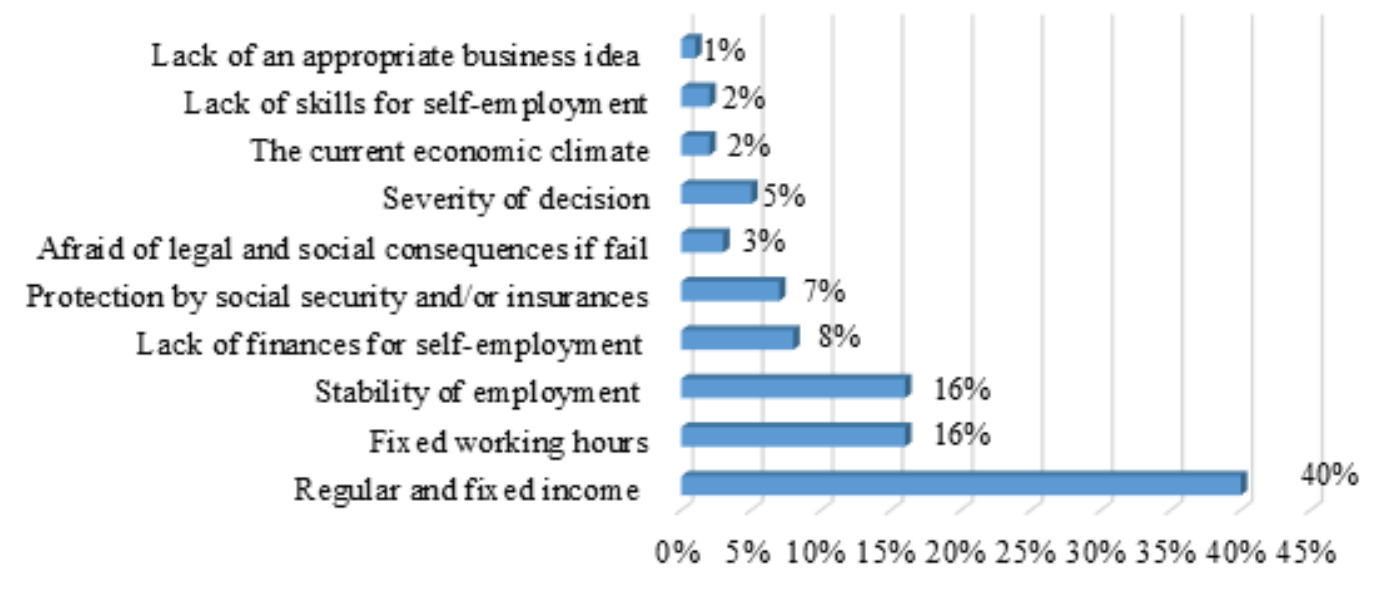

Figure 6: Reasons for preferring to be an employee rather than self-employed. Source: authors own calculations.

Regarding the elements that young potential entrepreneurs consider to be important when deciding to start up their own business, in the top of preferences is having an appropriate business idea and receiving the necessary financial support (see Figure 7). More than 60 percent of the respondents mentioned this two factors as being very important when deciding to start a new business. All the respondents considered that obtaining the financial resources is important or very important. Other factors mentioned as important for the decision to start up an own business are: contact with an appropriate business partner (more than 8 in 10 respondents chose this factor as important) and a role model (almost 3 in 10 respondents have chosen this factor).

Regarding the barriers that the respondents identify in starting up a new business, 9 of 10 respondents have indicated that the lack of available financial support is the most important obstacle for creating a new business (see Figure 8). Lack of funds was also found to be a barrier for the students interested in becoming entrepreneurs by several studies in the literature, such as: [9, 21--24, 39--42]. According to the OECD/ 
Dissatisfaction with regard to your previous situation

Addressing an unmet social or ecological need

A role model

Contact with an appropriate business partner

Receiving the necessary financial means

An appropria te business idea

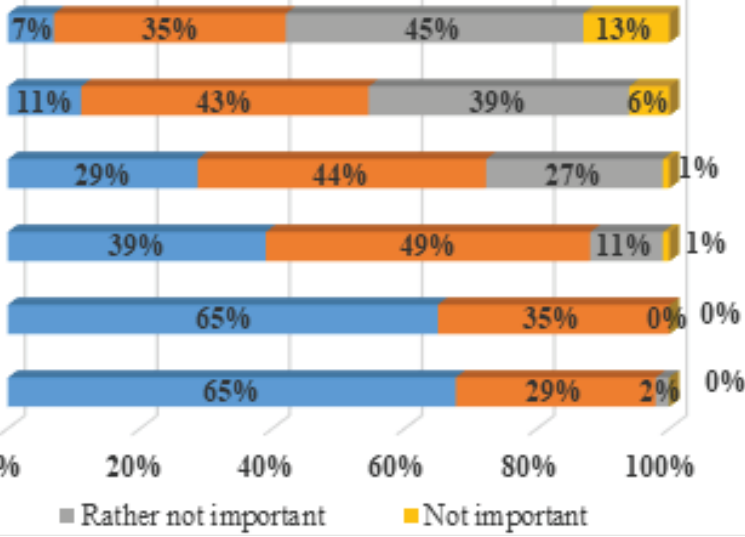

Figure 7: The importance of several factors when deciding to become entrepreneur. Source: authors own calculations.

European Commission [43], in the European countries, lack of financial support from private lenders is the most important obstacle to starting a business, especially by young people. Access to external funding, especially bank financing, is problematic for young people because they do not have a credit history and do not have assets to serve as collateral for the requested loans.

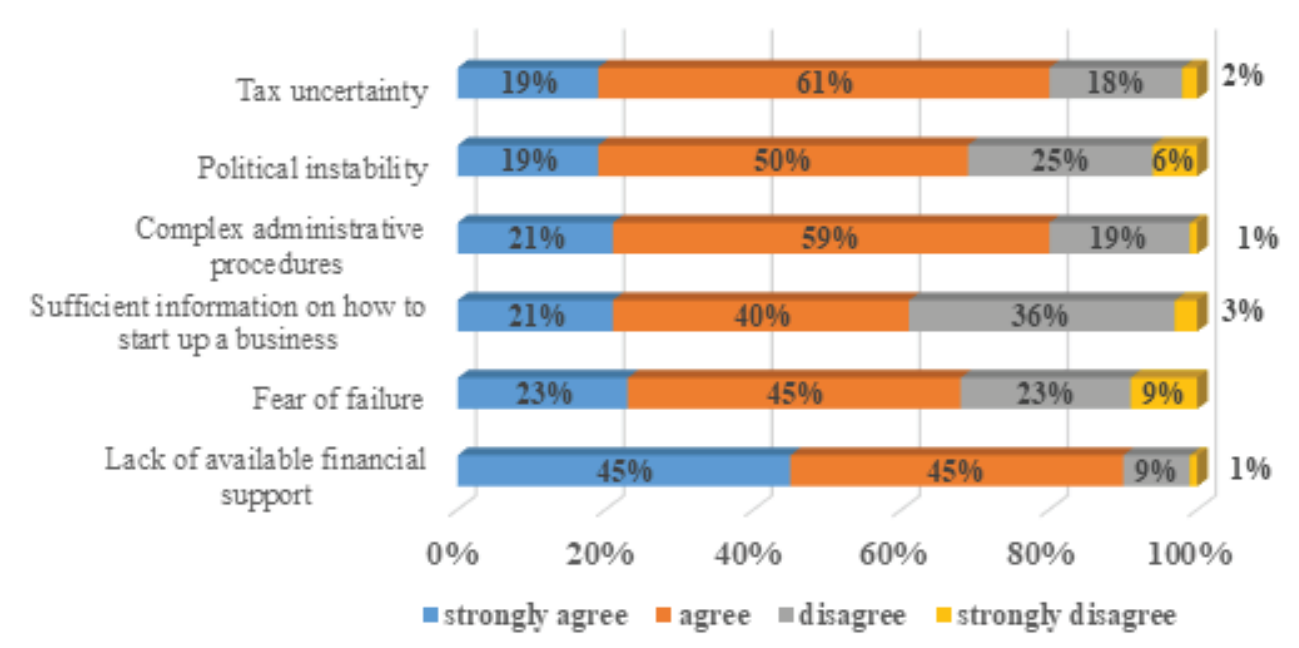

Figure 8: The barriers in starting up a new business. Source: authors own calculations.

Our survey indicates that fear of failure is a major barrier to starting a business by young people, more than 60 percent of respondents mentioned this obstacle in starting up new business. Our finding is in line with the research realised by Kew et al. [9], which shows that the European Union, compared to other regions, has the highest level of fear of failure among young people and adult populations. Some studies (for example, $[4,42])$ also mentioned fear of failure as one of the barriers for young people to entre 
in entrepreneurship. This fact emphasize that personal characteristics are playing a significant role for individuals when deciding to become self-employed, as shown also by several studies in the literature [24]. Access to information about how to start up a business (chosen by $61 \%$ of respondents) and fewer or easier administrative procedures (chosen by $80 \%$ ) are factors that would stimulate a bigger number of young individuals to decide to become entrepreneurs.

Asked about their knowledge regarding the procedures needed to start a new business the answers were somewhat equilibrated: 54 percent of the respondents said they know which are the necessary procedures for starting a new business, and 46 percent that they do not know. As regards the potential sources of financing they could use in the early stage of their business, 72 percent of the young potential entrepreneurs declared that they knew them, and 38 percent that they don't. We expected these results, maybe higher percentages, taking into account that the respondents are students at the Faculty of Economics and they study aspects of business creation and administration at their courses.

Because of their young age usually students who start a new business do not have sufficient collateral and credit history, therefore obtaining the traditional financing, such as credit cards or bank loans is very difficult or sometimes impossible [44]. So for financing their early stage business they turn to personal savings and to funds coming from family and/or friends [9, 45--48].

Personal savings are the most accessible source of financing new enterprises. Our survey shows that 79 percent of the respondents consider personal savings as being accessible or rather accessible (see Figure 9). Our result is similar with the findings from the literature $[1,9,49]$. After personal savings, bank loans are the main source of finance used by newly established enterprises. Bank loans represent the relevant form of external financing for 47 percent of the European Union Small and Medium Enterprises, as shown by SAFE Report [50]. Moreover, a bank loan is likely to improve the survival chances of a new small business [51] and brings positive effects in terms of revenue growth and firm survival [52].

The third financing source, classified according to accessibility, is represented by the European funds. The European Union promotion of EU funds for businesses has had positive results lately, increasing individuals' perception regarding their accessibility. In the Horizon 2020 Programme, under the SME Instrument, SMEs and start-ups receive grants between 50.000 euro and 2,5 million euro from European Union [53].

The decision makers in Romania tried to improve the situation regarding access to finance for start-ups and for young entrepreneurs, but still have to work on it. Between 


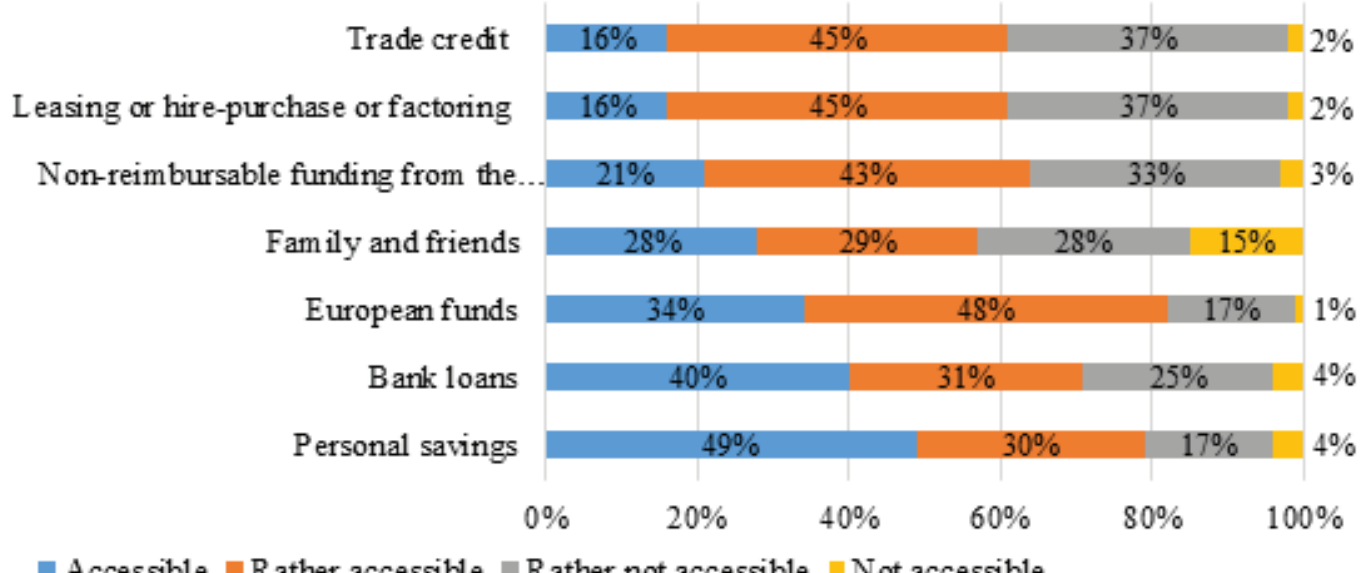

Figure 9: The perception about accessibility of the main sources of financing. Source: authors own calculations.

2010 and 2014, funding for start-ups and training have been available for young people within a programme of the Ministry of Economy, Commerce and the Relationship with the Business Environment, called: Program for the development of entrepreneurial skills among young people and facilitation of access to finance -- START. In 2015 and 2016 the programme was not targeting young people, but all start-ups, for all ages entrepreneurs. Also, in 2011, was introduced a start-up grant scheme specifically for young people (up to the age of 35) without prior experience in business. In 2014, the age criterion was dropped to ensure access for all "debutant" entrepreneurs. In addition to the grant (up to a maximum of EUR 10,000), the scheme offers exemptions from social security contributions and registration fees for the Trade Register. Since 2014, this grant scheme is part of the National Youth Guarantee Implementation Plan.

More recent, in 2017 and 2018, the Ministry for the Business Environment, Commerce and Entrepreneurship launched a programme dedicated to funding new business called Start-Up Nation - Romania. The programme is similar with the programmes implemented in the past, using funding from the European Social Fund to support start-ups with a maximum of 200000 lei (about 44000 Euro) [54]. The programme supports small start-ups creating at least one job and viable for at least 2 years after the first year when they have been funded.

Asked about the obstacles that might appear when trying to get a bank loan the respondents mentioned insufficient collateral or guarantee (37\%) and high interest rates or commissions charged by banks or creditors (31\%) as the main obstacles (see Figure 10). Other obstacles identified in the way of obtaining a bank loan were: bureaucracy $(10 \%)$, the abusive clauses of banks (9\%), lack of transparency of the credit assessment 


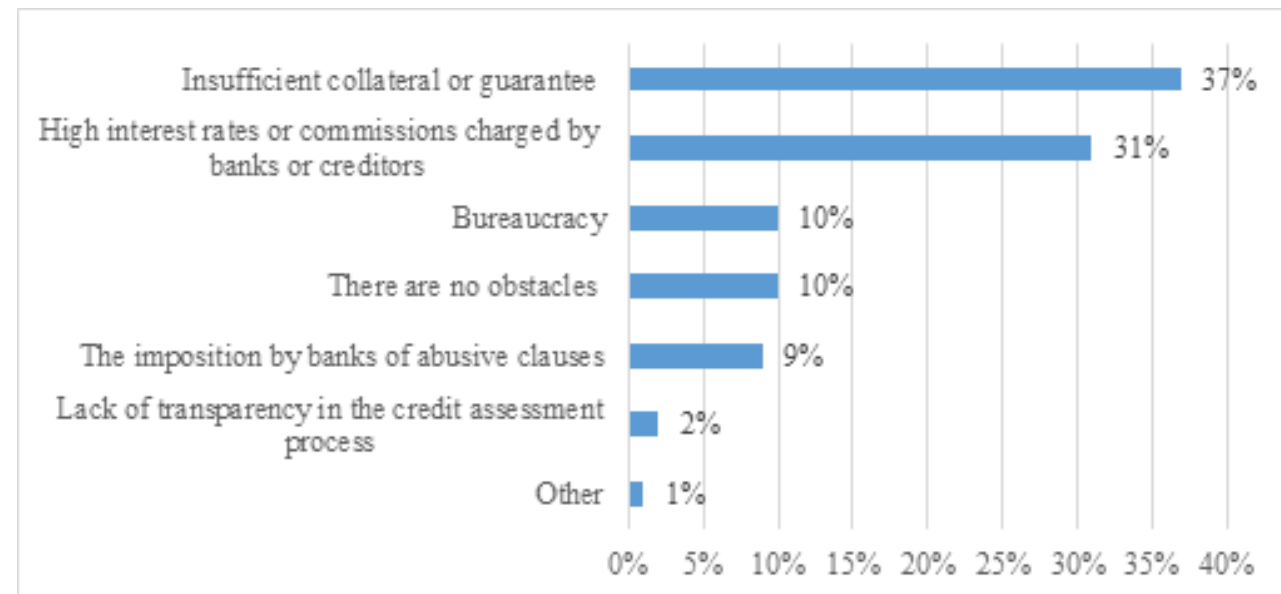

Figure 10: The most important obstacle in getting bank loans. Source: authors own calculations.

process (2\%). Only 1 in 10 respondents considered that there is no obstacle in obtaining a bank loan for a newly established enterprise.

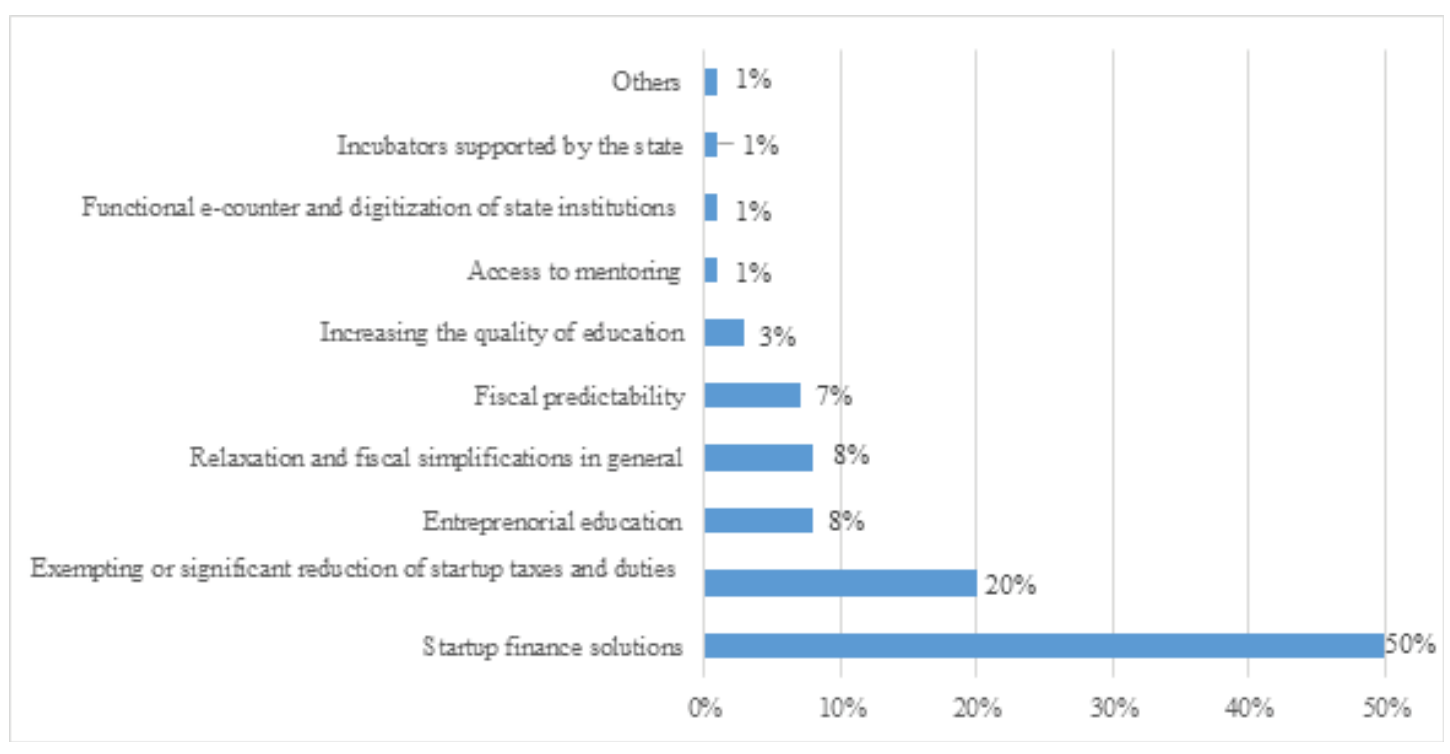

Figure 11: The government measure with the biggest impact in supporting potential entrepreneurs. Source: authors own calculations.

Half of the participants to our study answered that the government measure that would have the biggest impact in supporting potential entrepreneurs would be offering more financing solutions for start-ups (see Figure 11), confirming once again the significant role played by easy access to sources of financing for potential entrepreneurs. Also, another significant measure would be, exempting or significantly reducing of startup taxes, answer chosen by 20 percent of the respondents. As also shown by other studies [55], the implication of the decision makers in sustaining firm at the beginning of the road attracts students to start business and get involved in the business activities. 


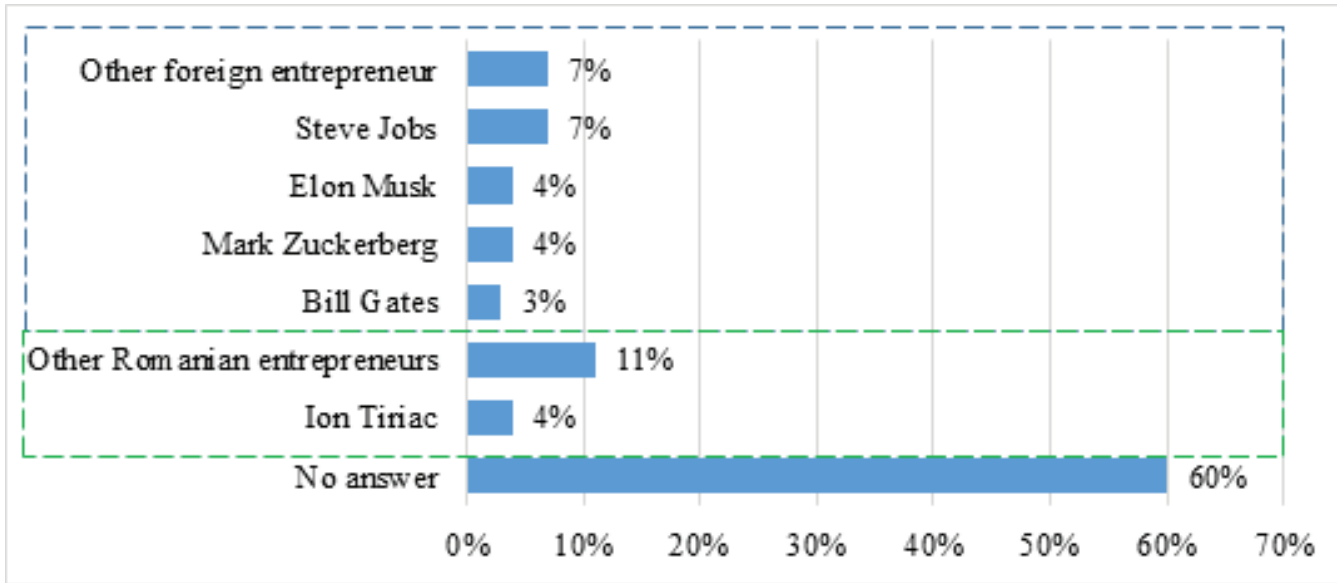

Figure 12: The most inspirational entrepreneur for young potential entrepreneurs. Source: authors own calculations.

The most inspirational entrepreneur for the potential young entrepreneurs is a foreign one (see Figure 12), Steve Jobs, which was the co-founder and CEO of Apple Computer Company, as well as Pixar's CEO, until it was purchased by the Disney animation studio. He was also the largest shareholder of Disney company. Mark Zuckerberg, Facebook's founder and CEO was ranked second, same as Elon Musk, entrepreneur, CEO Tesla Motors and founder SpaceX and PayPal, and Bill Gates co-founder of Microsoft Corporation. From the Romanian entrepreneurs, the most inspirational entrepreneur is Ion Tiriac. Also, were mentioned other national recognized entrepreneurs. Only 40 percent of those interviewed answered to this question. More than 60 percent of those who answered chose a foreign entrepreneur as a role model and almost 40 percent chose a Romanian entrepreneur. The results obtained from our study are similar to those obtained by Business Startup Barometer in Romania [30].

\section{Conclusion}

As concluding remarks, we point out that entrepreneurs, both young and old, play a key role in economic growth. Moreover, youth entrepreneurship is seen as one of the instruments to mitigate the problem of unemployment of this population.

Our results show a high level of entrepreneurial intentions among the interviewed students, respectively 60 percent, thus, more than half of the respondents intend to become entrepreneurs. These findings point out that there is a positive outlook of the young individuals from Romania toward entrepreneurship. Also, they emphasize the important role played by easy access to financial resources for young potential entrepreneurs. Facilitating access to sources of funding for potential entrepreneurs is a 
very important measure that decision makers have to adopt, given that young people often have no credit history or assets that could be offered as collateral when a loan is requested. Governmental decision makers should promote policies that allow young entrepreneurs greater access to finance, and should facilitate access to funding by providing guarantees for credits requested by young people, providing incentives to financial institutions that credit young people who want to start a business or have their own business.

Also, in Romania, similar to other developing countries there is a need of developing alternative funding models to help young people overcome financial obstacles. Such models include crowdfunding platforms, collaborating with financial institutions, developing micro-credit programs.

Our findings contribute to the literature by highlighting the need of the decision makers and also of the universities to work together to encourage the creation of new enterprises. The decision makers should increase the facilities granted to newly established firms and to young entrepreneurs, by creating new programmes. Also, they should facilitate the dissemination of information regarding the procedures for starting new businesses and also regarding the access to funding sources, by promoting the funding programs provided by adding to the target audience also university students, seeing them as potential entrepreneurs. The universities should facilitate interaction between experienced entrepreneurs and students, to give a more practical perspective to entrepreneurial education, because the development of entrepreneurial skills in young people contributes to increasing their employability. For example, the universities should facilitate the organization of periodical workshops where the students would have the possibility to talk with real entrepreneurs of all kinds (early stage entrepreneurs and experienced ones). Also, should be organized some classes where students would have to create their own firm that will carry out its activity during the years of study, fictional companies but for the functioning of which the students would have to be involved as in their own company.

A limit of the study is that the survey by questionnaire used in our study is limited to students from the Faculty of Economics and Business Administration. Thus, in the future research we intend to extend our analyzis by applying the questionnaire to other potential entrepreneurs, students from other universities, other specializations, and also to go out of the field. 


\section{Acknowledgement}

This work was supported by a grant of the "Alexandru Ioan Cuza" University of lasi, within the Research Grants program, Grant UAIC, code GI-UAIC-2017-02.

\section{References}

[1] Schøtt, T., Kew, P., and Cheraghi, M. (2015). Future potential: A GEM perspective on youth entrepreneurship 2015. London: Global Entrepreneurship Research Association. Available at: https://www.gemconsortium.org/report (Accessed on 25 January, 2019).

[2] Ferrante, F., Federici, D., and Parisi, V. (2016). University Students and Entrepreneurship Some Insights from a Population-Based Survey. MPRA Paper no., 76980. Available at: https://mpra.ub.uni-muenchen.de/76980/1/MPRA_paper_76980.pdf (Accessed on 10 February, 2019).

[3] Youth Business International. (2012). Youth Enterprise: Unlocking Ambitions, Creating Growth. London: YBI.

[4] Holienka, M., Pilková, A., and Jancovicová, Z. (2016). Youth entrepreneurship in Visegrad countries. Entrepreneurial Business and Economics Review, vol. 4, no. 4, pp. 105-121.

[5] Eurofound. (2016). Start-up support for young people in the EU: From implementation to evaluation. Luxembourg: Publications Office of the European Union.

[6] LSE Enterprise Limited (London School of Economics and Political Science). (2018). Youth entrepreneurship in Mediterranean partner countries. Available at: https://cor.europa.eu/en/engage/studies/Documents/entrepreneurship-youthmediterranean.pdf (Accessed on 28 April, 2019).

[7] European Commission. (2013). Entrepreneurship 2020 Action Plan. Reigniting the entrepreneurial spirit in Europe, COM (2012) 795 final, Brussels.

[8] OECD/European Commission. (2014). Policy Brief on Access to Business Startup Finance for Inclusive Entrepreneurship: Entrepreneurial Activities in Europe. Luxembourg: Publications Office of the European Union.

[9] Kew, J. et al. (2013). Generation entrepreneur? The state of global youth entrepreneurship. Youth Business International and Global Entrepreneurship Monitor, London. 
[10] Holienka, M., Pilková, A., and Jancovicová, Z. (2016). Youth entrepreneurship in Visegrad countries. Entrepreneurial Business and Economics Review, vol. 4, no. 4, pp. 105-121.

[11] Simoes, N., Crespo, N., and Moreira, S. B. (2016). Individual determinants of selfemployment entry: What do we really know?. Journal of Economic Surveys, vol. 30, no. 4 , pp. 783-806.

[12] Dvouletý, O. (2018). Determinants of self-employment with and without employees: Empirical findings from Europe. International Review of Entrepreneurship, vol. 16, no. 3, pp. 405-426.

[13] Dunn, T., and Holtz-Eakin. D. (2000). Financial Capital, Human Capital, and the Transition to Self employment: Evidence From Intergenerational Links. Journal of Labor Economics, vol. 18, no. 2, pp. 282--305.

[14] Ho, Y. P., and Wong, P. K. (2007). Financing, regulatory costs and entrepreneurial propensity. Small Business Economics, vol. 28, no. 203, pp. 187-204.

[15] Zain, Z. M., Akram, A. M., and Ghani, E. K. (2010). Entrepreneurship Intention among Malaysian Business Students. Canadian social science, vol. 6, no. 3, pp. 34-44.

[16] Liñán, F., Rodríguez-Cohard, J. C., and Rueda-Cantuche. J. M. (2011). Factors affecting entrepreneurial intention levels: a role for education. International Entrepreneurship and Management Journal, vol. 7, no. 2, pp. 195--218.

[17] Mouselli, S., and Khalifa, B. (2017). Entrepreneurship in crisis: the determinants of Syrian students' entrepreneurial intentions. Business, Management and Education, vol. 15, no. 2, pp. 159-173.

[18] Fragoso, R., Rocha-Junior, W., and Xavier, A. (2019). Determinant factors of entrepreneurial intention among university students in Brazil and Portugal. Journal of Small Business \& Entrepreneurship, pp. 1-25. doi: 10.1080/08276331.2018.1551459

[19] Turker, D., and Selçuk, S. S. (2009). Which factors affect entrepreneurial intention of university students?. Journal of European industrial training, vol. 33, no. 2, pp. 142-159.

[20] Dvouletý, O. et al. (2018). 'Scarred' young entrepreneurs. Exploring young adults' transition from former unemployment to self-employment. Journal of Youth Studies, vol. 21, no. 9, pp. 1159-1181.

[21] Kristiansen, S., and Indarti, N. (2004). Entrepreneurial intention among Indonesian and Norwegian students. Journal of Enterprising Culture, vol. 12, no. 1, pp. 55--78.

[22] Veciana, J. M., Aponte, M., and Urbano, D. (2005). University students' attitudes towards entrepreneurship: a two countries comparison. The International Entrepreneurship and Management Journal, vol. 1, no. 2, pp. 165--182. 
[23] Keat, Y., and Ahmad, S. (2012). A study among university students in business startups in Malaysia: Motivations and obstacles to become entrepreneurs. International Journal of Business and Social Science, vol. 3, no. 19, pp. 181-192.

[24] Kvedaraite, N. (2014). Reasons and obstacles to starting a business: experience of students of Lithuanian higher education institutions. Management -- Journal of Contemporary Management Issues, vol. 19, no. 1, pp.1--16.

[25] Business Development Bank of Canada (BDC). (2009). Entrepreneurial Self-Assessment: Are you the entrepreneurial type?. Available at: https: //www.bdc.ca/en/articles-tools/entrepreneur-toolkit/business-assessments/pages/ self-assessment-test-your-entrepreneurial-potential.aspx (accessed on 20 January, 2019).

[26] Lee, K., and Ashton, M. C. (2004). Psychometric properties of the HEXACP Personality Inventory. Multivariate Behavioral Research, vol. 39, no. 2, pp. 329-358.

[27] Bezzina, F. (2010). Characteristics of the Maltese entrepreneur. International Journal of Arts and Sciences, vol. 3, no. 7, pp. 292 -- 312.

[28] Tiftik, H., and Zincirkiran, M. (2014). A Survey of Entrepreneurial Tendencies Candidate Young Entrepreneurs: Foundation University Sample. Journal of Management Research, vol. 6, no. 2, pp. 177-200.

[29] Kerr, S. P., Kerr, W., and Xu, T. (2017). Personality Traits of Entrepreneurs: A Review of Recent Literature. Harvard Business School, Working paper 18-047.

[30] EY Romania. (2017). Business Start-up Barometer in Romania. Business eco-system at the beginning of the road, Second edition (Barometrul afacerilorde tip start-up din România. Ecosistemul afacerilor la început de drum. A doua edit囚ie). Available at: https://www.impacthub.ro/wp-content/uploads/2019/01/EY_Barometrul-startupurilor-din-Romania-2017.pdf (Accessed on 20 January, 2019).

[31] European Commission. (2010). Flash Eurobarometer, no. 283, Entrepreneurship in the EU and beyond, A survey in the EU, EFTA countries, Croatia, Turkey, the US, Japan, South Korea and China, Analytical report. Available at: http://ec.europa.eu/ commfrontoffice/publicopinion/flash/fl_283_en.pdf(Accessed on 20 January, 2019).

[32] Aghion, P., Fally, T., and Scarpetta, S. (2007). Credit constraints as a barrier to the entry and post-entry growth of firms. Economic policy, vol. 22, no. 52, pp. 732-779.

[33] Klapper, L., Amit, R., and Guillén, M. F. (2010). Entrepreneurship and firm formation across countries, in International Differences in Entrepreneurship, 129-158. Chicago: University of Chicago Press. 
[34] Vidal Suñé, A., and López Panisello, M. B. (2013). Institutional and economic determinants of the perception of opportunities and entrepreneurial intention. Investigaciones Regionales, vol. 26, pp. 75-96.

[35] Sayed, O., and Slimane, S. B. (2014). An appraisal of the determinants of entrepreneurship in developing countries: The case of the Middle East, North Africa and selected Gulf cooperation council nations. African Journal of Social Sciences, vol. 4, no. 4, pp. 63-74.

[36] Arin, K. P. et al. (2015). Revisiting the determinants of entrepreneurship: A Bayesian approach. Journal of Management, vol. 41, no. 2, pp. 607-631.

[37] UNCTAD. (2015). Policy Guide on Youth Entrepreneurship, Available at: https: //unctad.org/en/PublicationsLibrary/webdiaeed2015d1_en.pdf(Accessed on 20 January, 2019).

[38] European Commission. (2019a). Eurostat. Available at http://ec.europa.eu/eurostat (Accessed on 28 April, 2019).

[39] Henderson, R., and Robertson, M. (1999). Who wants to be an entrepreneur? Young attitudes to entrepreneurship as a career. Education + Training, vol. 41, no. 5, pp. 236-45.

[40] Turnbull, A. et al. (2001). Entrepreneurship education, does it work?, in Enterprise and Learning. Aberdeen: University of Aberdeen.

[41] Lane, D. (2002). Hopes and aspirations of young achievers on the young enterprise programme. Working paper, Bristol Business School, Bristol.

[42] Robertson, M. et al. (2003). Barriers to start-up and their effect on aspirant entrepreneurs. Education + Training, vol. 45, no. 6, pp. 308-316.

[43] OECD/ European Commission. (2012). Policy brief on youth entrepreneurship: Entrepreneurial activities in Europe. Luxembourg: Publications Office of the European Union.

[44] Ozgen, E., and Minsky, B. D. (2013). Why some college students engage in entrepreneurial activities while others do not. Journal of Entrepreneurship Education, vol. 16, no. 1, pp. 45--58.

[45] Bird, B. J. (1989). Entrepreneurial Behavior. Glenview, IL: Scott, Foresman and Company.

[46] Van Auken, H. E., and Neeley, L. (1996). Evidence of bootstrap financing among small start-up firms. Journal of Entrepreneurial and Small Business Finance, vol. 5, no. 3, pp. 235-249. 
[47] Winborg, J., and Landström, H. (2001). Financial bootstrapping in small businesses: examining small business managers' resource acquisition behaviors. Journal of Business Venturing, vol. 16, no. 3, pp. 235-254.

[48] Edelman, L. F. et al. (2016). The impact of family support on young entrepreneurs' start-up activities. Journal of Business Venturing, vol. 31, no. 4, pp. 428--448.

[49] Daniels, C., Herrington, M., and Kew, P. (2016). Global Entrepreneurship Monitor 2015/2016: Special Report on Entrepreneurial Finance. London: Global Entrepreneurship Research Association. Available at: Available at: https://www. gemconsortium.org/report (Accessed on 25 January, 2019).

[50] European Commission. (2018). Survey on the access to finance of enterprises (SAFE). Analytical Report 2018. Luxembourg: Publications Office of the European Union.

[51] Åstebro, T., and Bernhardt, I. (2003). Start-up financing, owner characteristics, and survival. Journal of Economics and Business, vol. 55, no. 4, pp. 303--319.

[52] Cole, R. A., and Sokolyk, T. (2018). Debt financing, survival, and growth of start-up firms. Journal of Corporate Finance, Vol. 50, no. June, pp. 609--625.

[53] EU Startup Services. (2019). EU funding Opportunities for Startups and SMES. Available at: http://www.eustartupservices.eu/old/eu-funding-opportunities-for-startupsand-smes/ (Accessed on 10 February, 2019).

[54] European Commision. (2019a). EACEA national policies platform. Start-up funding for young entrepreneurs -- Romania. Available at: https://eacea.ec.europa.eu/nationalpolicies/en/content/youthwiki/39-start-funding-young-entrepreneurs-romania (Accessed on 10 February, 2019).

[55] Papulová, Z., and Papula, J. (2015). Entrepreneurship in the Eyes of the Young Generation. Procedia Economics and Finance, vol. 34, pp. 514 -- 520. 